\title{
Migrants, land markets and carbon emissions in Jambi, Indonesia: Land tenure change and the prospect of emission reduction
}

\author{
Gamma Galudra • Meine van Noordwijk • \\ Putra Agung • Suyanto Suyanto • Ujjwal Pradhan
}

Received: 22 February 2013 / Accepted: 10 September 2013 /Published online: 18 October 2013

(C) The Author(s) 2013. This article is published with open access at Springerlink.com

\begin{abstract}
Policies designed to reduce land-based carbon emissions require a good understanding of the complex connections between state-sanctioned concessions, forest conversion, informal land markets and migrants. Our case study in the peat forests of the Tanjung Jabung Barat (TanJaBar) regency of Jambi, Indonesia aimed to explore relations between four key stakeholder groups: the state, local communities, migrants, and state-sanctioned concessions. We hypothesized that current land use patterns are shaped by insecurity in formal forest tenure alongside informal land tenure arrangements with migrants. In analyzing the six two-way relationships between the four stakeholder groups, we found that interactions between the stakeholders have changed local norms and practice, causing land conflicts and contested claims that need to be explicitly addressed in efforts to reduce carbon emissions in TanJaBar. Relational concepts of land rights between migrants and local community leaders are informed by social identity, expectations of investment opportunities, insecure customary forest tenure and competing land use policies. Migrants act as intermediaries in shaping the land tenure system and shift the balance of power between local communities, the state, and business concessions. We conclude that effective and equitable implementation of national Reducing Emissions from Deforestation and Forest Degradation+ (REDD+) programs will need to recognize underlying land ownership dynamics, power struggles and strategic positioning among stakeholders across scales. Obtaining free and prior informed consent (FPIC) from all relevant stakeholders is a major challenge given this complexity. Low emission development strategies will require recognition of a reality beyond large-scale concessions and traditional local communities.
\end{abstract}

Keywords Conflict · Customary rights · Deforestation · FPIC · NAMA · Power relations · REDD $+\cdot$ Tenure security

\section{Introduction}

As outlined in other contributions to this special issue, Indonesia has committed itself to reduce carbon emissions by establishing a Nationally Appropriate Mitigation Action (NAMA) plan that details the voluntary actions that will be made with state-budget funding to reduce emissions by $26 \%$ below the 2020 business as usual scenario and by a further $15 \%$ with

G. Galudra $(\bowtie) \cdot$ M. van Noordwijk $\cdot$ P. Agung $\cdot$ S. Suyanto $\cdot$ U. Pradhan World Agroforestry Centre, Southeast Asia Regional Office, Bogor, Indonesia e-mail: ggaludra@cgiar.org 
international assistance, including the emerging incentive mechanisms to reduce emission from deforestation and degradation (REDD + ). The attempt to achieve integration across sectors and emission sources raises challenges. These include understanding the complex ways in which local economies relate to the national economy, and navigating demographic transitions, particularly migration into forest margins and away from degraded or fully utilized lands. For REDD+, high standards of transparency and social safeguards have been formulated and incorporated into the principles of free and prior informed consent (FPIC) that seek to guarantee that all relevant stakeholders are involved in the discussions of high carbon stock development pathways as an alternative to the current high carbon emission trajectories (Jagger et al. 2012; Minang et al. 2012; Minang and van Noordwijk 2012). The right to FPIC requires governments and project proponents to ensure that REDD + is implemented in a way that fully respects the rights of affected communities. This means that the objectives and methods of the REDD+ project are openly discussed, that communities participate in developing a detailed project plan, and that consent to the implementation of the project is correctly obtained (Anderson 2011). Understanding the forces and actors driving deforestation is a key priority because any changes in policies designed to contain deforestation are likely to fail if they are not based on realistic scenarios of how the social processes involved operate and how they may change.

Much of current policy discourse on REDD+ is still framed in terms of public and private forest management (Angelsen and McNeill 2012), or as a triangle of state, local communities and largescale concessions (Ribot and Larson 2012; Wright 2012; Di Gregorio et al. 2013). The roles of migrants and migration appear to be undervalued in this triangle; a fourth stakeholder group may therefore have to be added to the conceptualization of the deforestation issue (Ekadinata et al. 2013). Although earlier studies have examined the role of migration in deforestation, and the likely consequences for global climate change (Cassels et al. 2005; Gaveau et al. 2009; Elmhirst 2001; Elmhirst 2011), far less scientific attention has been directed towards the land arrangements of migrants interacting with business concessions, government agencies, and local communities, and their historical influence on local norms and practice, forest tenure and environmental change.

This paper therefore explores the social relationships between four stakeholder groups: the state (government institutions), local communities, migrants and state-sanctioned concessions. It assesses their impact on deforestation and forest tenure insecurity in the coastal peat swamp area of the Tanjung Jabung Barat (TanJaBar) regency, Jambi Province, Indonesia. Although migrants in their areas of origin have property right traditions based on family relations, different tenure constructs are required in new locations. Migration brings distinct tenure ideas and constructs into contact with those established in the new locale, through interactions between settlers, local communities, and state institutions, bringing a supply-demand based land market into the established tenure arrangement. This transition is underpinned by pluralism, and no single authority (including the state) is seen as fully legitimate and able to implement rules regarding land claims (Unruh 2008).

While migration typically results in conflicts between local communities and migrants (van Klinken 2008), the social relationships between new and established communities in this case study extend beyond conflict. Sometimes migration eventually generates relationships of solidarity and interdependence at the local level, but tenure conflicts with business concessions and state agencies may still develop. Based on initial diagnostic studies in TanJaBar, we framed a hypothesis proposing that current land use patterns in this high-emission area are shaped by insecurity in formal forest tenure alongside informal land tenure arrangements with migrants.

The following questions are addressed:

1. What are the effects of six specified interactions between the four major groups of stakeholders seen (see next section on the Conceptual Framework) in the forest area of TanJaBar? 
2. How and why have tenure arrangements been changed? And in what ways are they continuing to change? How did migrants initially access the forest? And how do they currently access it?

3. What are the strategies for these four stakeholder groups to claim rights to forest areas in TanJaBar? What conflicts have arisen, and how is this changing in the light of carbon emission reduction policies?

4. How would policies designed to contain deforestation be improved by understanding of the above three questions?

\section{Conceptual framework}

The conceptual framing of this study recognizes four major stakeholder groups and highlights six two-way interactions between them (Fig. 1). These groups are:

A. The state and its lower levels of government (provincial, district and sub-district) that have been partially empowered as part of the decentralization and devolution process;

B. Local communities that have obtained a more direct link with local government and elites through local elections;

C. Concessions that obtain logging, mining, or plantation rights from the state, and the associated labor force (mostly migrants);

D. Migrant settlers, both pioneers and followers.

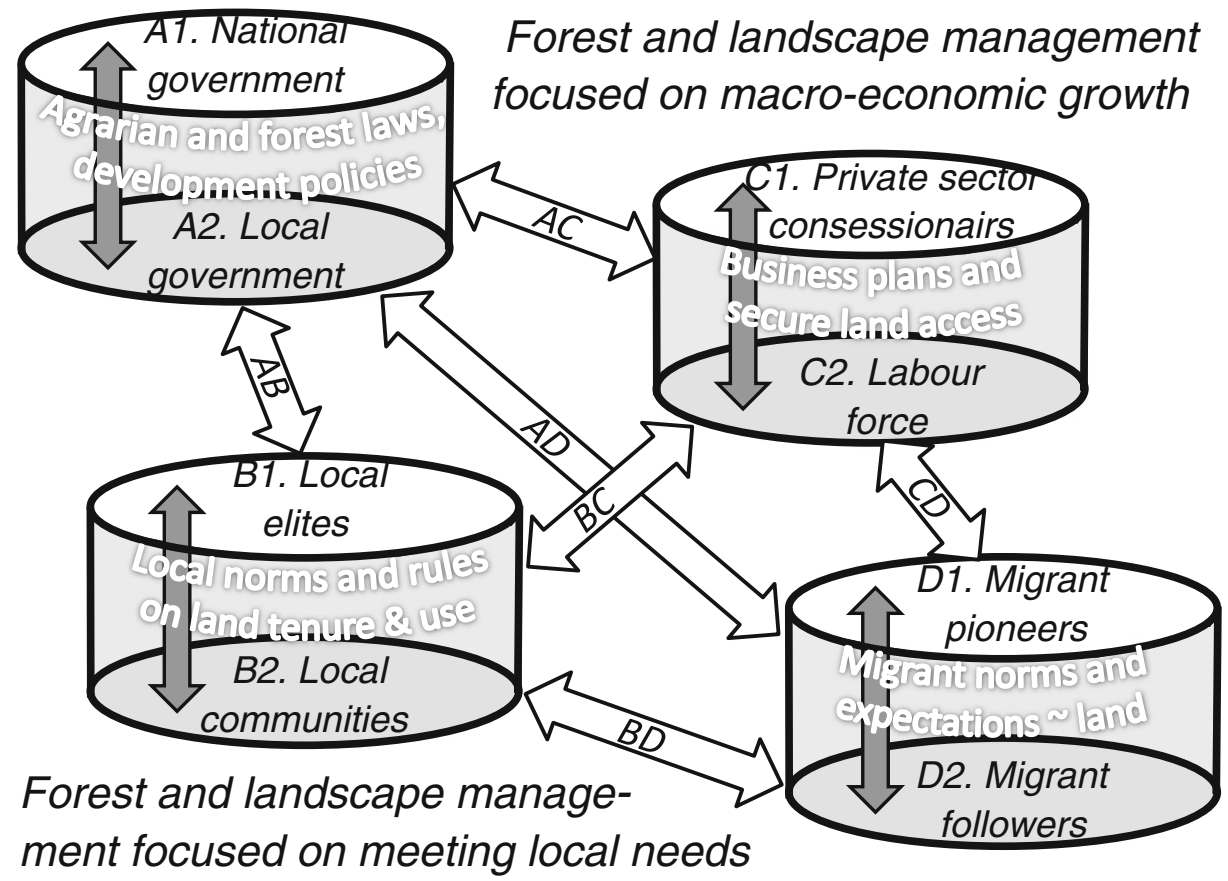

Fig. 1 Complexity of social actors in the forest margins of Sumatra and their multiple interactions affecting land use, demography and development 
Each stakeholder group (or subsystem) has its own internal hierarchies of power and influence, and its own norms of behavior, rules, and power of enforcement. All six two-way interactions between these four subsystems can be of importance and can affect land tenure and ownership in the forest area: 1) A-B: local communities with government institutions; 2) A-C: government institutions with business concessions; 3) A-D: government institutions with migrants, 4) B-C: local communities with concessions; 5) B-D: local communities with migrants; 6) C-D: migrants with concessions. Understanding the six two-way relations will help towards the dynamics of the 4-way interactions.

Although many studies discuss some of these relations (Batterbury and Bebbington 1998; Bebbington et al. 2006; Ribot et al. 2006; Wardell and Lund 2006; Elmhirst 2011), relatively few formal case studies explore these six interactions simultaneously, or acknowledge and integrate changes to the norms, rules and expectations of each stakeholder group. This integrated approach is also relevant to studies of other rural areas in the developing world that are experiencing large inflows of migrants seeking land and interacting with large-scale external investors who obtain concessions from state agencies. The results are also informative for those attempting to combat deforestation and reduce emissions.

Migrants, as the intermediary actors who influence land tenure change and conflicts, are generally motivated by the prospect of obtaining land and more reliable livelihood options than they had in their home areas. Migration involves not only the movement of people, but also the movement of investment, norms and skills. In Indonesia, several case studies have documented the sale of land by communities to migrants seeking land for cash-crop production (Barkmann et al. 2010; Bayuni 2007; Elmhirst 2001; Li 2002; Potter and Badcock 2004). To achieve the sale of land, village and regency elites may change the customary tenure arrangement in an attempt to maintain their position and guarantee political support from the migrants (Bayuni 2007).

The interaction of migrant and non-migrant tenure approaches has often resulted in a 'clearing to claim' process, with severe deforestation repercussions (Unruh et al. 2005). As Fearnside (2008) explained for Brazil, this correlation between the land market and deforestation in the Amazon involves multiple land claimants. The process starts with public land being invaded by individual migrants and organized land speculators, and it is then purchased by settlers. If land is un- or under-utilized, squatters and landless migrants may reinvade the land, including land sold to capitalized farmers (both local and migrant). However, the decision for actors to pursue and enforce a claim is determined by the benefits expected from resource use, as well as the costs of enforcement (Galudra et al. 2011).

The links between local land tenure change, migration and deforestation have been investigated by Place and Otsuka (2001) and Platteau (1996). Both these studies argue that as local tenures change, local people eventually claim new land areas or protect customary access and pressure the government for the creation of formalized private property rights in the contested area. In contrast, the acquisition of land in forest margins is driven by open access, with tenure security arising from local authorities sanctioning the forest claim. Opportunistic migrants can claim and access forests due to a lack of state control, thereby creating opportunities for additional external actors to migrate to the area to clear the land and stake further claims (Haller and Merten 2008; Poffenberger 2009). Likewise, political instability and policy changes have caused confusion over tenure. Coupled with the ineffective rule of law and forest insecurity in certain areas, claiming land can be an attractive economic opportunity.

Hall et al. (2011) defines four modes of power used by actors engaged in contested land claims to prevent access by others when conflicts have erupted. These are regulation (formal and informal rules that govern access and exclusion), physical force, market expansion, and legitimization (justification of situations and appeals to moral values). Using this framework 
enables a more comprehensive analysis of how the (previous and existing) social relationships between these actors shape and determine current conflicts.

\section{Study site and methods}

\subsection{Tanjung Jabung Barat: a neglected hot spot in Jambi}

Tanjung Jabung Barat (TanJaBar) regency is located on the east coast of Jambi Province on the island of Sumatra, bordering Riau Province in the north. The regency has been mapped as having vast peatland (approximately $40 \%$ of the total area), with varying depths from very shallow $(1 \mathrm{~m})$ to very deep (just under $3 \mathrm{~m}$ ). In TanJaBar, $50 \%$ of land tenure is under the jurisdiction of the Ministry of Forestry (MoF) with production forest (hutan produksi, HP) as the largest designated status. The rest is designated as non-forest area (areal penggunaan lain, APL), dominated by coconut (Cocos nucifera) agroforestry, rubber (Hevea brasiliensis) agroforestry, rubber monoculture and, most recently, oil palm (Elaeis guineensis) (Mulia et al. 2013).

Large scale logging concessions were operating in TanJaBar in the 1970s and 1980s. Since the late 1990 s, the post-logging concession era has been marked by the abandonment of logged-over areas in various parts of the region. These logged-over areas were considered to be open access lands, and encroachments of various forms occurred, resulting in further clearing followed by different planting practices, especially oil palm plantation.

The study area discussed here shows that the movement of people and investment is in large part based on the expectation that illegally accessing and claiming forest area will eventually be rewarded at least by some security of tenure. However, when the MoF decided to reclaim the area and allocate it for industrial forest estates and forest protection, conflicts and land disputes with the 'encroachers' erupted.

TanJaBar has a population of approximately 280,000 people, nearly $50 \%$ of whom are migrants. The inland parts of the regency on mineral soil above sea level have a rubberbased land use pattern and a history similar to that described for the Bungo regency in Jambi (van Noordwijk et al. 2012). Upland villages were established in 1760 by inland people from western and northern Sumatra, while villages in the lowland area (peatland) were established by Malay people from Riau. This settlement was followed by several spontaneous influxes of migrants, such as ethnic Banjar people from Kalimantan in the 1920s, and ethnic Bugis and Javanese migrants in the 1930s and 1940s. Most of the Bugis are now second generation and have already settled in other parts of Sumatra. In the upland area, significant migration, mostly from Java, occurred in the 1980s and 1990s, through the transmigration program that was established by the Indonesian government and which helped to develop large-scale oil palm plantations and industrial forest estates. However, as the peatland area is strategically located both near the main river (which acts as a transportation route) and on the coast (which is the main trading area in TanJaBar), the lowland population is more dynamic than that of the upstream mineral soil areas. Consequently, land tenure conflicts in the peatland areas are more dynamic (more violent and involving more actors) than those in upland areas.

\section{Methods}

The study used the Rapid Land Tenure Assessment (RaTA) framework developed by ICRAF (World Agrorestry Centre). RaTa provides methods for exploring how competing claims among different actors are related to multiple and changing land tenure systems and policies 
(Galudra et al. 2010). These methods - through a combination of focus group discussions, policy document analysis, and in-depth interviews - help to enhance understanding of the importance of social relationships, including relations of power, in the enforcement of land tenure claims and in the constant process of creation, negotiation and contesting of these rights. The methodological framework includes: 1) description of the literature on land use and conflict linked to particular contexts: political, cultural, economic, and so on; 2) identification and analysis of actors; 3) identification of the various forms of perceived historical and legal claims made by actors; 4) identification of the institutions and rules governing the management of natural resources and analysis of the linkage of various claims to policy and (customary) land laws; and 5) discussion of policy interventions that enable the conflict resolution mechanism.

Content and historical policy studies were used to analyze the role of policy changes on land tenure change, conflicts and competing claims. In addition, the study used and modified methods developed by Koszberski et al. (2009) and Curry and Koszberski (2009) to examine the evolving relational concepts of land rights and land tenure arrangements that had been caused by the historical interactions between the four major stakeholder groups in TanJaBar.

Three field visits to TanJaBar, totaling more than 2 months of fieldwork associated with several research projects, were undertaken between March and December 2011. Fieldwork focused on five upland villages and four peatland villages that were selected as representative of different soil types, land use cover, accessibility, livelihood options, population densities, ethnicities, and the probability of carbon dynamics. The researchers immersed themselves in these nine villages to observe the daily lives of the local communities. Data were obtained from several sources (local villagers and elites, as well as pioneer migrants and followers), using a range of methodologies including key informant surveys, focus group discussions, and semi structured interviews. Purposive sampling techniques were used to select key informants (including knowledgeable representatives of both customary, migrant and state/administrative institutions), and participants for the focus groups. Informal interviews were conducted with members of customary landowning groups and elders who were personally involved in or knowledgeable about the tenure system used to access land, the sale of customary land and forests to outsiders, migration and the communities' historical case studies. Informal interviews were also undertaken with both members of local (customary) communities and migrants who cultivate and lay claim to state forest land. Informal interviews with local and central government officials were also conducted. Fifteen key informant interviews and nine focus group discussions were conducted in Jakarta, Jambi (Jambi Province) and Kuala Tungkal (West Tanjung Jabung Regency). These were supplemented with a range of other sources, including newspaper articles, government reports, and reports from NGOs and individual consultants. Direct observation also deepened the research team's understanding of local land tenure.

\section{Results}

5.1 The starting point: government institutions interacting with local communities (AB)

Interactions between government institutions (A) and local communities (B) are differentiated between the areas with a forest zone (kawasan hutan) designation and non-forest lands (APL). Almost $50 \%(238,000 \mathrm{ha})$ of the TanJaBar regency has permanent forest estate land status, where forestry policies play a major role in the allocation of concessions, and a process of degazettement is required for re-allocation to other land uses. Policies evolve at 
the central government level, which in turn affects the regency level, e.g. through issuance of small scale timber extraction and other concession permits. Within TanJaBar there have so far been no specific efforts to recognize customary forest management within forest estates, but forest concessions allocated to outsiders are seen by local communities as an infringement on their rights. None of the forest estate in TanJaBar has completed the formal gazettement process that is legally required for it to be managed as state forest (ContrerasHermosilaa and Fay 2005) but, as elsewhere in Indonesia, the Ministry of Forestry assumes that the forest estate has the legal status of state forest land.

\subsection{State government interacting with private concessions (AC)}

The long history of state forest governance in this regency began in the 1970s, when the Ministry of Agriculture (MoA) issued (forest concession) permits to log the forest. Logging operations during that period did not have a strong legal basis. In 1985, to support the legality of the concessions, the government enacted the Forest Allotment Consensus (Tata Guna Hutan Kesepakatan, TGHK) that classified 238,000 ha of forest in TanJaBar as forest zone (kawasan hutan) under the administration of the MoF. These policies laid a stronger basis for the MoF to issue logging concession permits over forest land.

In TanJaBar, at least seven logging concessions permits were issued to allow operation in production forest areas from the 1970s until the end of the 1990s. These logging concessions, supposedly based on selective logging that would allow natural forest regeneration over a 30-year period, came to an end at the beginning of the decentralization era in the early 2000s when some of the logging concession permits were revoked by the MoF. The end of the logging concession era created vulnerable conditions for the status of state forest zones and for forest cover. Ex-logging concession areas were abandoned and suffered from encroachment and illegal logging, which caused further deforestation and degradation. Abandoned areas were seen as de facto 'open access' and the government at that time was unable to control the situation. Due to heavy logging - beyond the intensities allowed - and encroachment, the remaining forest cover in 2009 was approximately 110,000 ha $(24 \%$ of the regency area): a decrease from 330,000 ha in 1990 (Widayati et al. 2011).

A major land use development within the forestry sector was the shift to pulp and paper industries that use trees of any diameter, with permits for clear-felling of degraded forest given in the context of conversion to plantation forestry to meet the ever-increasing demand of the mills. For TanJaBar, this trend was also apparent in the prominent allocation of forest plantation in forest management strategies. Since 2004, as much as $70 \%$ of the forested areas in TanJaBar was allocated for large-scale Acacia and Eucalyptus plantations. Many spontaneous migrants from Java arrived in the regency to work as wage laborers in these industries.

\subsection{State government interacting with migrants (AD)}

Aside from forestry and land use policies, development programs established by central government may also indirectly affect the local forest governance and land use changes in regencies such as TanJaBar. One such program is transmigration resettlement, which is usually implemented in the major outer islands. This program has been closely associated with the PIR-Transmigration program within the oil palm development industry. For TanJaBar, since 1990, the major impact of these policies was the release of 36087 ha of forest land to seven large-scale private oil palm plantation concessions. The high demand for labor on these plantations has led companies to cooperate directly with the Department of Transmigration in order to bring in laborers from outside the area (particularly from Java). 
Around 7396 transmigrants were settled in areas adjacent to oil palm plantations. This in itself put great pressure on the remaining forest as these migrants searched for more land, in addition to the land they had received from the transmigration program, in order to accumulate capital for planting oil palm. In most situations, spontaneous migration to this area from Java and other parts of Sumatra followed. With the unresolved land tenure issues resulting in a perception of 'open access' to forest land, the increase in cash crop areas came at the expense of forest land. This analysis is supported by the fact that in peat areas, the largest 'landholding' for oil palm is on state forest land.

\subsection{Local communities interacting with private concessions (BC)}

Along with the operations of logging companies in 1970s, communities who had customary claims to the area also opened up the natural forest, searching for commercial timber such as ramin (Gonystylus bancanus kurst). During this period, many Bugis spontaneous migrants (originally from Sulawesi) came from Riau Province to work on these sites as logging laborers. They also, exercised their livelihood practices as jelutung (dyera lowii) tappers in their homes.

The TanJaBar case study provides an example of how central government policy creates perceptions of open access to forests, leading to acute deforestation and competing forest claims. To respond to this situation, the central government launched the Kesatuan Pengelolaan Hutan (KPH, Forest Management Unit) scheme to conduct forest management in the remaining forest area (60700 ha) that was not under the control of forest plantation concessions. However, this newly established KPH faced problems, primarily land occupation by local people and migrants who converted the lands to small-scale oil palm farming.

\subsection{Local communities interacting with migrants (BD)}

The population increase and the modernization of production processes (which enables the development of larger areas) accelerate the expansion of croplands and increase competition for land access, both of which contribute to the transformation of land transactions. However, the situation in TanJaBar is different. Customary land tenure systems in the regency share four basic characteristics:

(a) Land belongs to a community (village), rather than to individuals;

(b) Differentiated tree tenure rights and land ownership inform the land tenure system (Janudianto et al. 2011);

(c) Land ownership has a sacred dimension that is part of the production and reproduction of that social group;

(d) Theoretically, land is inalienable: it cannot be sold.

These characteristics were enjoyed when land was in abundance. Local people could clear the forest as much as they were able. They just needed to request a piece of forest area to be cleared and cultivated from the chief of the territory (pesirah). The chief would then 'give' the applicant a piece of forest to be cleared and cultivated. During the $1800 \mathrm{~s}$ and 1900s, the first Minangkabau migrants (from the highlands of West Sumatra) were also given a piece of land as a gift from the pesirah when they arrived in the area. At that time, these migrants still followed the local farming system of shifting cultivation.

The Banjar people had the experience and technology to open and drain forest peatland in their place of origin in Kalimantan and this skill was used by the pesirah to open forest 
peatland. The local people of TanJaBar lacked this knowledge, thus providing the opportunity for the Banjar people to extend the village's claim of access to and territory in the forest peatland. Interestingly, although the Banjar people did lay claim to the opened forest land, but they did not lay claim to the drain construction as they would have done in their native land tenure system; instead they left it as an open access resource. This is almost certainly because they wanted to build a strong social relationship with the host groups. The local Malay people, who at that time partially depended on fishing grounds, could lay claim to fishing access as their communal right, and also gained an opportunity to claim forest peatland. The term parit (meaning the right to drain and open forest peatland) was commonly used after the arrival of the Banjar people to this area.

This pattern of land acquisition remained valid for subsequent migrants, up until the influx of Banjar, Bugis and Javanese people (mostly arriving as part of the transmigration program) reached its peak in the late 1980s and early 1990s. Rubber had been introduced to and cultivated in Jambi since 1904, using a slash and burn system. By the 1960s, this form of rubber cultivation resulted in a gradual change from communal land to private land, which made it possible for local people to sell or lease their land to the new migrants. The land sale or lease become imminent after the enactment of the Village Law of 1979. After the enactment of the Village Law of 1979, which replaced the local administration unit (following the Javanese model), the power to control land allocation has gradually been vested in village leaders (rather than pesirah), and it remains this way at the time of writing.

By the late 1980s, land obtained as a gift from the village leader was no longer generally considered to be legally valid as problems of land scarcity had become apparent and no more land was distributed to the newcomers. The Forest Consensus Allotment in 1985 designated forested areas as state forest zone (kawasan hutan) and, within these areas, large scale plantations started to operate, resulting in decreasing areas of swidden available for newcomers. Land transfer institutions were a relatively new phenomenon for the TanJaBar people and were forbidden by the village leaders and customary land tenure systems at the time of the new legislation.

However, despite these customary restrictions, rubber had been introduced to and cultivated in Jambi since 1904, using a slash and burn system. By the 1960s, this form of rubber cultivation resulted in a gradual change from communal land to private land, which made it possible for local people to sell or lease their land to the new migrants. Before the 1960s, under the communal rights system, swidden-paddy cultivation was an important livelihood in this area. The long term cultivation of perennial cash crops (which gradually replaced traditional swidden-paddy cultivation by local communities) has induced de facto changes in land tenure regimes. Rights to use and benefit are increasingly being vested in the same family or individuals for extended periods, leading some villagers to claim exclusive rights of access to, and inheritance of, these resources. In effect, land rights are being individualized as land is excised from the communal pool of land that is governed by communal tenure.

In this context of customary land law, land rights can be claimed using two principles. The first principle emphasizes rights derived from first clearance of land. The second refers to the principle of 'land to the tiller', whereby rights are obtained by using land for a certain period of time. In TanJaBar, the first principle mainly applied to the peatland areas, where coconut plantations were established around 1980 and until the 1990s, during the period when Banjar migrants first opened up the peatland forest. The second principle applied to upland forest where rubber planting was introduced in the $1960 \mathrm{~s}$, gradually changing communal land into private land.

Finding this an open opportunity to negotiate with the 'land owners', the Bugis and Javanese then introduced and practiced a land transaction called bagi tanah (land share tenancy) as a way to obtain access to land resources. However, the adoption of a land market is not solely caused 
by the interest shown by migrants. As Li (2002) found in Sulawesi, Indonesia, local smallholders changed the existing resource access and social relations because they wanted to invest their land and labor in a new global crop, which ultimately resulted in the abandonment of their traditional farming systems. This has also been the case in TanJaBar.

Determined by a consensus or contract, land-share tenancies mostly support the cultivation of annual crops (cash crops), dominated by oil palm. In other peatland areas, coconut is also cultivated using this kind of arrangement. The cost of production, including the labor wage, is covered solely by the migrants until harvest yield, which is around 8 years for oil palm. Most importantly, the contract/consensus contains a description of the share of the land that the tenant can keep after the initial plot is divided into two parts. The migrants invest and plant the initial plot with oil palm and the local landowner retains and benefits from half the planted land. This transaction not only helps the migrants to access and accumulate land resources as well as a surplus of oil-palm production, it also gives the local people a simple way to gain access to the necessary technology and capital for oil palm plantation. It also provides a certain level of tenure security for the migrants to cultivate within the state forest land.

This model of tenancy is also applied to coconut in peatland areas. From 2000 to 2009, many Bugis migrants from Riau (Sumatra) tried to expand the land they had available for coconut plantation. Coconut was very common in their homeland around 1990, marking a boom period for copra production, with high market demand from Singapore. Most of the coconut they planted in peatland was mixed with betel nut and coffee, which was developed together as coconut agroforest. Figure 2 shows how this relationship between local communities, migrants and village elites changed the land tenure system, giving all parties the opportunity to access and use the forest area.

Purchasing customary land through 'sale' is another method used by the migrants. A purchase transaction has become an increasingly important means to secure land access. To secure their purchase process, migrants seek a letter of land utilization (surat keterangan tanah) from the village leader. Then, the migrants can apply to the regency's Land Affairs Office (Badan Pertanahan Nasional) for the official land titles to this private land (hak milik). During our fieldwork, we found that much forest land had been claimed using this title. Indeed, there have been numerous cases of migrants being harassed by members of the landowning group, especially by younger local members, and instances where the land 'purchased' by migrants has been reclaimed by the customary landowners, especially where the land was previously used for shifting cultivation. For these reasons, migrants prefer to buy land that is covered by monoculture plantation, as this land can be claimed customarily as private land, rather than purchasing shrub areas, which have commonly been used for shifting cultivation.

\subsection{Migrants interacting with concessions (CD)}

The outcomes of decentralization policies change the nature of the power relations between central and local government institutions, as well as their respective relationships with local communities (McCarthy 2004; Rosyadi et al. 2005). However, competing claims of authority over forest areas mainly resulted from uncertainty about the legal status of the relationship between Spatial Planning (endorsed by the Provincial government in 1993) and Forest Allotment Consensus (endorsed by the MoF in 1982). Since 1993, some forest areas in TanJaBar that have been designated by the Forest Allotment Consensus have become sites of conflict between the industries (concessions) and the locals and migrants working the land. In peatland areas, approximately 8740 ha of forest plantation concession areas are currently 


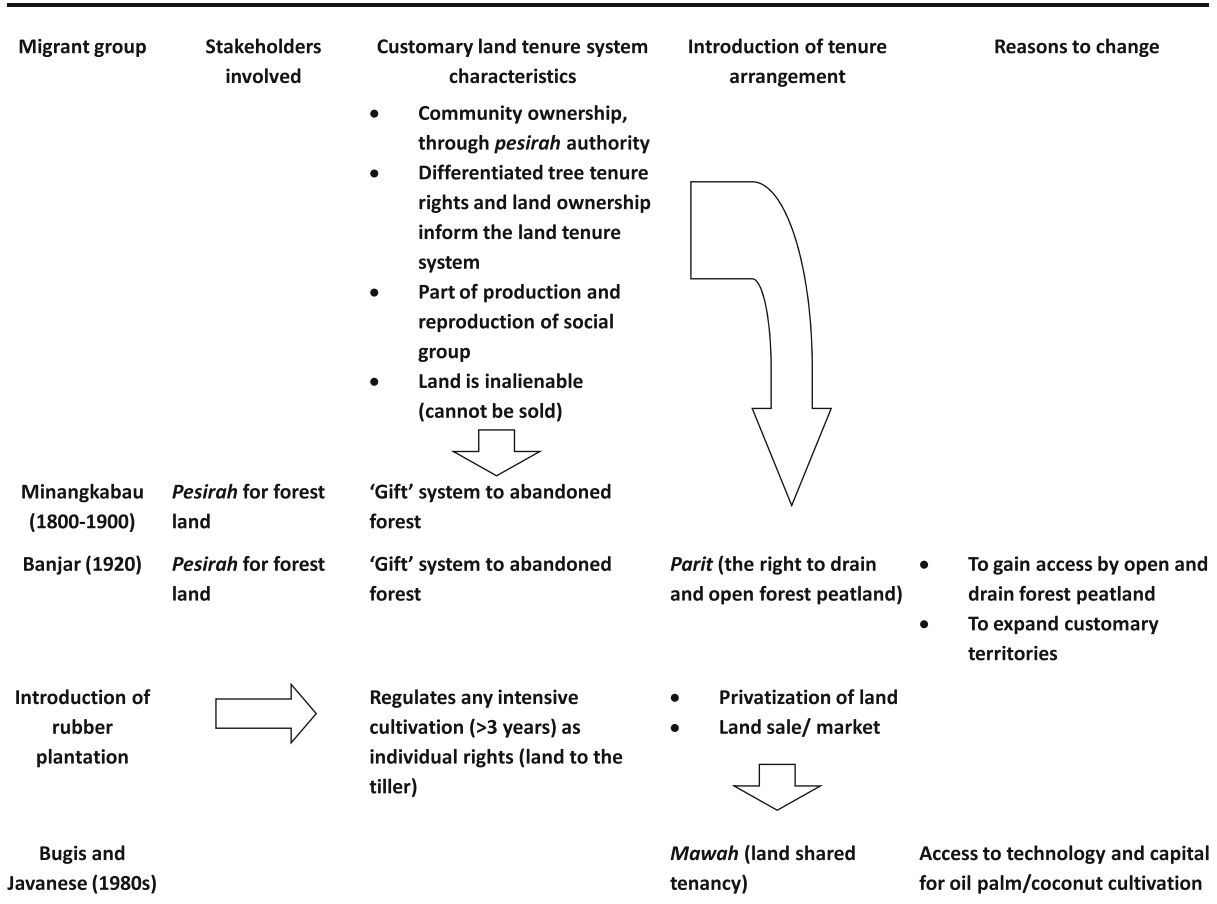

Fig. 2 The process of tenure change by the migrants and their introduction of new tenure arrangement

being claimed by local people (in 2013). This conflict has occurred primarily because of confusion arising from overlapping land-use policies; the conflict stems from the argument that the area being claimed was categorized as non-forest area (APL) in the Regency Spatial Planning document of 1993, which currently remains under revision. From a forest plantation concession perspective, the area claimed by local communities is a conversion production forest (hutan produksi konversi), according to the Forest Allotment Consensus of 1985.

In this peatland area, one of the 'hot spot' conflicts is located in Senyerang village. In 2010, two men were shot, and one of them died, during a demonstration against a pulp and paper plantation company. Around 1500 people were involved in the demonstration. The conflict started in 1997, when the MoF agreed to the plantation company's request to increase the area of the concession in TanJaBar from 35580 ha to 43750 ha. As the Jambi provincial government agreed to increasing the area, the MoF issued the Decree No 64/KptsII/2001 that designated the area as production forest (hutan produksi).

When the area was being demarcated in 2002, around 7224 ha of community land was identified as part of the new production forest area. This communal area had been used since the 1920s, when many Banjar migrants opened and drained forest peatland. Some of the migrants had received documentary proof of ownership when their access rights were recognized by pesirah during the Dutch colonial period. Protests from local communities were recorded, but the company still converted the area into Acacia plantation. At that time, the regency government supported the change in forest status and its designation from nonstate forest into state forest, based on Regional Government Regulation No 52/2002.

But the situation changed dramatically during the regency elections of 2010 . One of the candidates promised these villagers that their land would be given back if he became the head of the regency (bupati). Knowing that they had some support, as well as assistance 
from the local farmers' organization in Jambi, the villagers tried to retrieve their land from the company by force, but failed to get it back. When the candidate won and was elected as bupati, the villagers became increasingly aggressive as a new regency land use plan that designated this contested land as APL was enacted. At first, the company refused to negotiate but, as pressure - particularly from the bupati-increased, the company was willing to negotiate and agree to the villagers' demand for co-management of the rubber plantation. While the villagers have gained rights and access to the land, the details of benefit sharing remain under negotiation.

Conflict over access to forest peatland has also occurred in other parts of TanJaBar. In Bram Itam, a peatland area, many villagers (mainly migrants) claimed the peatland forest for oil palm plantation. The area had previously been used for wood extraction by logging concessions but was abandoned in the 1990s. Some Banjar migrants opened and drained the peatland forest and 'sold' the land to arriving Bugis migrants from Riau Province for use as oil palm plantation. When the Regency Forest Agency tried to take control of this converted forest in 2009, it was faced with resistance from the migrants. This situation triggered the creation of a forest replanting program by the Regency Forest Agency that promoted the planting of jelutung (Dyera costulata) amongst the oil palm. However, realizing that this strategy would fail (as the migrants would oppose the program with force, as others had in the Senyerang village incident), the Regency Forest Agency is now considering changing the status of the forest land into non-forest land. However, this action will certainly create conflict with the MoF, which wants to protect the peatland area as part of a national emissions reduction plan.

The problem of competing land claims, however, occurs not only in peatland areas, but in upland areas too. Around 20585 ha of forest allocated to the pulp and paper industries are currently being occupied by locals and migrants who favor oil palm plantations. Around half of these occupied areas are being pushed through as private property rights for oil palm development by the Regency Forest Agency, but no approval has thus far been given by the MoF.

\section{Discussion}

\subsection{Adaptive tenure arrangement and conflicts of state forestland}

In this study of TanJaBar, it has been shown that land conflicts have occurred due to historical interactions between state, business concessions, local communities and migrants. These interactions and the subsequent conflicts shape and change the relational concepts of land rights and land tenure arrangements in the area. Both land use policies leading to the issuance of concessions and the release of forest land status to large-scale plantations clearly support palm oil production and the pulp and paper industries. This change in land use policies and the lack of enforcement to protect natural resources by the state led to an 'open access' situation which, in turn, has resulted in acute deforestation.

The arrival of migrants (largely since the 1920s) and new cash crops, such as oil palm (in the 1980s), has added a new tenure arrangement (informal land market) to the customary local tenure system. The informal land market is a strategy for introducing a new tenure arrangement to local people, whereby migrants are not only able to gain access to the customary forest area, but are also given the opportunity to gain membership status of the local customary community (Melayu Jambi). Migrants seeking land and aiming to invest in 'abandoned' forest areas and local communities seeking opportunities to gain profits from new cash crops (as well as re-claiming or expanding their customary land in forest areas) 
both play critical roles in land conflict as they challenge the authority of the MoF and business concessions. The fear of having their land confiscated - especially land designated as state forest - by private companies or government projects often drives locals to use landshared tenancies with migrants, as a part of a strategy to protect their land. Migrants are now seen as integral to the local communities' strategies for realizing and protecting their local land rights from government or private sector encroachment and inequitable resource allocation. Despite this, the role of the village leaders in land use allocation is crucial to the changing process of tenure arrangement. Village leaders still have the power to determine land allocation and the capacity to issue documents legitimizing possession by migrants. The village administration is not run by an organizational apparatus, but solely by the village leader. This system has essentially been inherited from the earlier system of pesirah and it seems to be widely accepted in this function. Village leaders invited migrants to their villages when they were seeking political support during village elections. During the elections, the migrants would be sure to vote for the incumbent village leader in order to strengthen their relationship and ensure protection of their future position in the village.

Changes to tenure arrangements are also caused by the lack of coordination between the $\mathrm{MoF}$ and the local government in TanJaBar; both are in competition for authority over land allocation. These conditions have resulted in uncertainty and contestation over land use and allocation, leading to conflicting land claims and forest tenure insecurity. These tensions have worsened due to the slow progress made towards harmonizing Spatial Planning arrangements at the regency and provincial (Jambi) levels, as well as problems with the Forest Allotment Consensus due to the complexity of land use allocation. Land claims and conflicts have occurred not only as a result of land use allocation policies, but also as a result of the de facto open access situation caused by this confusion over authority.

Through the informal land market, claimants refer to customary land rights and social identity to argue that the forest area legitimately belongs to them, to the exclusion of others. Claims can also be strengthened with endorsement from the head of the regency (bupati). In addition, the assistance of the local farmers' organization is often sought. After decentralization in 1999, local communities have obtained a more direct link with local government through the electoral system, enabling them to negotiate their demands with the help of the local authorities against the MoF and business concessions. With this support, they have also become more overt in their opposition, using land occupations and river blockades to exclude business concessions from the forest.

Despite these collaborative efforts and the fact that migrants are often warmly welcomed to become members of the customary village, their access to and use of forest land remains vulnerable. Migrants still need to maintain a special social relationship with the village elite and/or register their land with the regency land agency in order to secure their land access and use, whereas locals are more able to rely on their historical presence in the contested area.

Figure 3 shows the application of the power of exclusion to the six interactions, based on Hall et al. (2011). Based on this current scenario, the six interactions have changed local norms and practice, forest tenure and land use. They also have created conflicts, resulting in these stakeholders making new alliances and developing strategies to exclude others from claiming the land.

\section{Concluding remarks: implications for FPIC and REDD+}

This paper has examined the processes by which migrants gain and change customary land tenure, as illustrated not only by the 'selling' of land, but also by the expansion and 


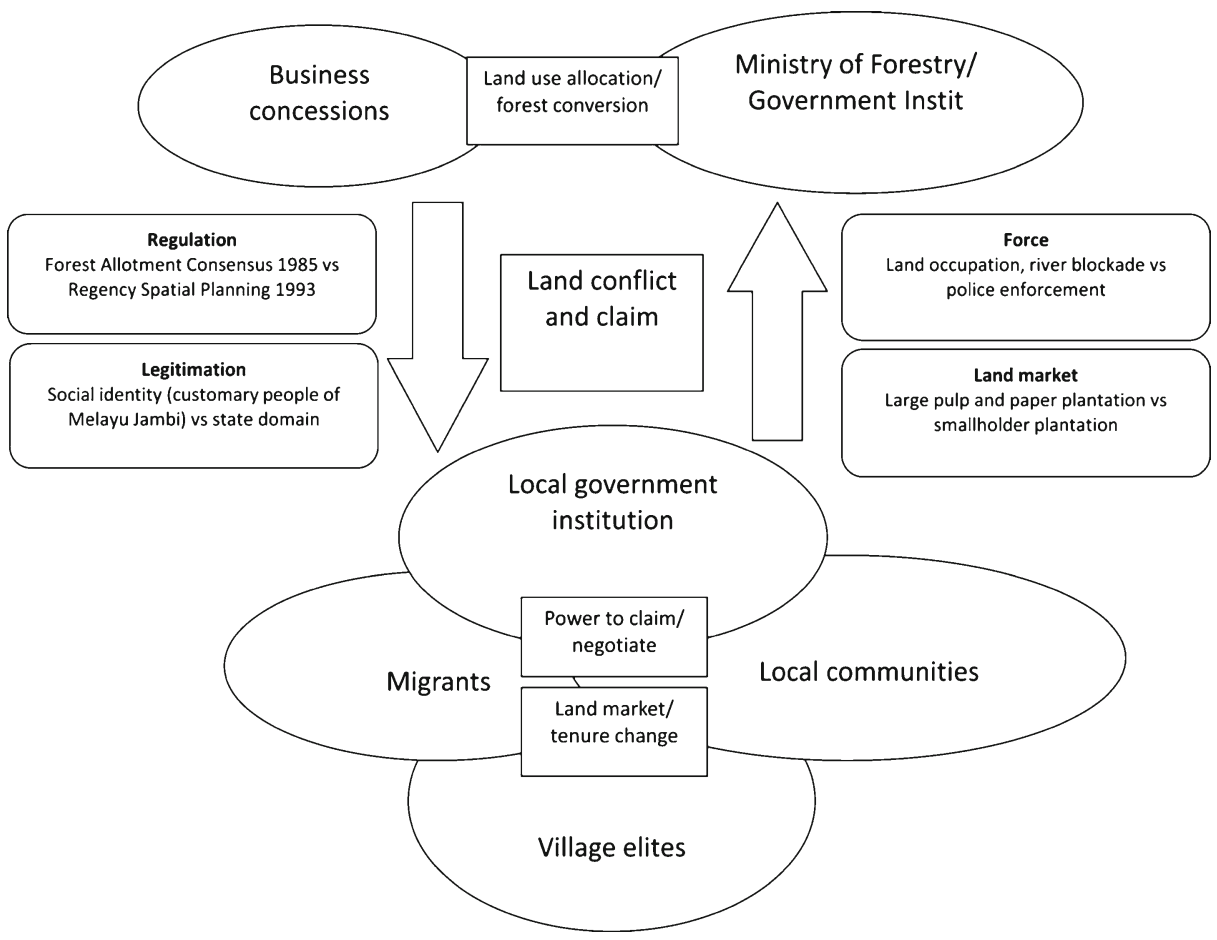

Fig. 3 The social relationship after the tenure conflicts by the stakeholders and their modes of power

strengthening of customary territories within designated state forest land. Achieving additionality (a reduced rate of emissions from degradation and deforestation compared to the baseline) at the local level may have wide implications for all forest users. The attainment of FPIC in REDD+ projects has mostly focused on local communities and customary groups. Given their vulnerability, it is quite reasonable to focus on these groups, but it is also important to bring migrants into the equation. When REDD+ projects are implemented, it is not only peoples' livelihood, welfare and income that are affected, but also their social order, identity and culture (Anderson 2011).

Nevertheless, this study shows that the interactions of multiple stakeholders (migrants, local communities, private concessions and government institutions) in the current situation have changed local norms and practice, forest tenure, and the rate of environmental change, causing land conflict and contested claims that affect the prospects for emissions reduction in TanJaBar. As Dewi et al. (2011) note, negotiations among multi-stakeholders will be needed in order to achieve alternative high $\mathrm{C}$-stock development pathways, thus implying that FPIC should also be required from these multiple stakeholders during the negotiation process, as they determine the land use system and rights to forest.

On closer scrutiny, both migrants and locals tend to conceptualize land rights and customary land tenure within the context of benefits and costs, especially when claiming state forest land as customary land. In these types of land transactions, migrants can forge a social identity as part of the customary community and, in the process, strengthen their access rights to land. On the other hand, customary land tenure is being modified and adapted to reflect the migrants' own land tenure system. The new system has been 
introduced not only to accommodate migrants' interest in land acquisition, but also to expand and strengthen customary land tenure over state forest land.

The decision to sell off land is profoundly shaped by the insecure tenure of local communities over the designated state forest zone. The interactions that have taken place with migrants have developed a new land market arrangement that is perceived as offering more security to both migrants and local communities. Here, the migrants and local communities gain legitimacy through customary rights to forest area. Nonetheless, they also seek regulatory and legitimatizing power, as well as the use of force, as additional ways to strengthen their claim over that forest area. However, these efforts also create conflicts with other actors, such as concessions and government authorities, thus increasing the level of uncertainty surrounding land tenure security. Understanding the fluctuating power relationships among these actors is crucial to understanding land tenure dynamics at the local level. In this interaction, migrants act as intermediaries in shaping the land tenure system and creating a new balance of power between local communities, the government authorities and business concessions.

While it is recognized that the implementation of REDD+ actions can pose a number of risks, including the loss of traditional territories and rights, there is increasing consensus that REDD+ initiatives will require clear and secure land and forest rights for indigenous peoples and local communities. This is explicitly mentioned in the Indonesian-Norway Letter of Intent signed in 2010, as well as in the National Emission Reduction Plan (RAN-GRK) based on Presidential Decree No 61/2011. Thirteen provinces, including Jambi, have proposed to sign up as REDD pilot provinces in Indonesia. Several donors and international organizations are exploring effective ways of reducing emissions in Indonesia via emerging REDD schemes that integrate consideration of land tenure systems and communities' rights. Nonetheless, only a few REDD+ initiatives currently recognize migrants and their influence over land tenure, and note how they shape and interact with other actors (stakeholders) who also lay claim to and access the forest. It is increasingly important to consider how the emergence of new land markets can be managed as part of the REDD+ safeguards against deforestation.

Acknowledgments The research for this paper received funding from the European Community's Seventh Framework Programme [FP7/2007-2013] under grant agreement No 226310, Climate Land Use Alliance (CLUA) under grant agreement No 10-0191, Reducing Emission from Any Land Use (REALU) and CRP 2 Policies, Institutions and Markets. It is part of the CGIAR Research Program on Forests, Trees and Agroforestry. The authors wish to thank Jenny Farmer, Douglas White, Kristell Hergoualc'h, and Andrew Wardell for their input and suggestions on earlier drafts. We also thank three anonymous reviewers whose comments improved the text considerably.

Open Access This article is distributed under the terms of the Creative Commons Attribution License which permits any use, distribution, and reproduction in any medium, provided the original author(s) and the source are credited.

\section{References}

Angelsen A, McNeill D (2012) The evolution of REDD. In: Angelsen A, Brockhaus M, Sunderlin WD, Verchot LV (eds) Analysing REDD+: Challenges and choices. CIFOR, Bogor, pp 31-49

Anderson P (2011) Free, prior and informed consent: Principles and approaches for policy and project development. RECOFTC and GIZ, Bangkok

Barkmann J, Burkard G, Faust H, Fremerey M, Koch S, Lamni A (2010) Land tenure rights, village institutions, and rainforest conversion in Central Sulawesi (Indonesia). Environ Chang 1:141-160. doi:10.1007/978-3-642-00493-3-6, Cited 30 June 2012

Batterbury SPJ, Bebbington AJ (1998) Environmental histories, access to resources and landscape changes: an introduction. Land Degrad Dev 10:279-291 
Bayuni S (2007) Unfinished business: customary land individualization in Olilit Village, Tanimbar Islands. http://mpra.ub.uni-muenchen.de/918/. Cited 25 June 2012

Bebbington AJ, Dharmawan L, Guggenheim S, Fahmi E (2006) Local capacity, village government and the political economy of rural development in Indonesia. World Dev 34(11):1958-1976

Cassels S, Curran SR, Kramer R (2005) Do migrants degrade coastal environments? Migration, natural resource extraction and poverty in North Sulawesi, Indonesia. Hum Ecol 33(3):329-363

Contreras-Hermosilla A, Fay CC (2005) Strengthening forest management in Indonesia through land tenure reform: Issues and framework action. Forest Trends, Washington, 55

Curry GN, Koczberski G (2009) Finding common ground: relational concepts of land tenure and economy in the oil palm frontier of Papua New Guinea. Geogr J 175(2):98-111

Dewi S, Ekadinata A, Galudra G, Agung P, Johana F (2011) LUWES: Land use planning for low emission development strategy. World Agroforestry Centre SEA Regional Office, Bogor

Di Gregorio M, Brockhaus M, Cronin T, Muharrom E, Santoso L, Mardiah S, Büdenbender M (2013) Equity and REDD+ in the media: a comparative analysis of policy discourses. Ecol Soc 18(2):39. doi:10.5751/ ES-05694-180239, Cited on 30 July 2013

Elmhirst R (2001) Resource struggles and the politics of place in North Lampung, Indonesia. Singap J Trop Geogr 22(3):284-306

Elmhirst R (2011) Migrant pathways to resource access in Lampung's political forest: Gender, citizenship and creative conjugality. Geoforum 42:173-183

Ekadinata S, van Noordwijk M, Budidarsono S, Dewi S (2013) Hot spots in Riau, haze in Singapore: the June 2013 event analyzed. ASB Policy brief No. 33. Nairobi: ASB Partnership for the Tropical Forest Margins. p. 6

Fearnside PM (2008) The roles and movements of actors in deforestation of Brazilian Amazonia. Ecol Soc 13(1): 23. http://www.ecologyandsociety.org/vol13/iss1/art23/. Cited 21 June 2012

Galudra G, van Noordwijk M, Suyanto S, Sardi I, Pradhan U, Catacutan D (2011) Hot spots of confusion: contested policies and competing carbon claims in the peatlands of Central Kalimantan. Int For Rev 13(4):431-441

Galudra G, Sirait M, Pasya G, Fay C, Suyanto S, van Noordwijk PU (2010) RaTA: A rapid land tenure assessment manual for identifying the nature of land tenure conflicts. World Agroforestry Centre, Bogor

Gaveau DLA, Linkie M, Suyadi LP, Williams NL (2009) Three decades of deforestation in Southwest Sumatra: effects of coffee prices, law enforcement and rural poverty. Biol Conserv 142(3):597-605

Hall D, Hirsch P, Li TM (2011) Powers of exclusion: Land dilemmas in Southeast Asia. National University of Singapore

Haller T, Merten S (2008) “We are Zambians: don't tell us how to fish”. Institutional change, power relations and conflicts in Kafue Flat Fisheries in Zambia. Hum Ecol 36:699-715

Jagger P, Lawlor K, Brockhaus M, Gebara MF, Sonwa DJ, Resosudarmo IAP (2012) REDD+ safeguards in national policy discourse and pilot projects. In: Angelsen A, Brockhaus M, Sunderlin WD, Verchot LV (eds) Analysing REDD+: Challenges and choices. CIFOR, Bogor, pp 301-316

Janudianto, Mulyoutami E, Joshi L, Wardell DA, van Noordwijk M (2011) Recognizing traditional tree tenure as part of conservation and REDD+ strategy: Feasibility study for a buffer zone between a wildlife reserve and the Lamandau river in Indonesia's REDD+ Pilot Province. ASB Policy Brief No. 22. Nairobi, Kenya. ASB Partnership for the Tropical Forest Margins. p. 4

Koczberski G, Curry GN, Imbun B (2009) Property rights for social inclusion: migrant strategies for securing land and livelihoods in Papua New Guinea. Asia Pac Viewpoint 50(1):29-42

Li TM (2002) Local histories, global markets: cocoa and class in upland Sulawesi. Dev Chang 33(3):415-437

McCarthy JF (2004) Changing to gray: decentralization and emergence of the volatile socio-legal configurations in Central Kalimantan, Indonesia. World Dev 32(7):1199-1223

Minang PA, van Noordwijk M (2012) Design challenges for achieving reduced emissions from deforestation and forest degradation through conservation: leveraging multiple paradigms at the tropical forest margins. Land Use Policy, doi:10.1016/j.landusepo1.2012.04.025. Cited 31 September 2012

Minang PA, van Noordwijk M, Swallow B (2012) High-carbon-stock rural development pathways in Asia and Africa: How improved land management can contribute to economic development and climate change mitigation. In: Nair PKR, Garrity DP (eds) Agroforestry: The future of global landuse. Springer, The Netherlands

Mulia R, Widayati A, Suyanto S, Agung P, Zulkarnain MH (2013) Low carbon emission development strategies for Jambi, Indonesia: simulation and trade off analysis using FALLOW model, this issue

Place F, Otsuka K (2001) Population, tenure, and natural resource management: the case of customary land area in Malawi. J Environ Econ Manag 41:13-32

Platteau JP (1996) The evolutionary theory of land rights as applied to Sub-Saharan Africa: a critical assessment. Dev Chang 27:29-86

Poffenberger M (2009) Cambodia's forests and climate change: mitigating drivers of deforestation. Nat Res Forum 33:285-296 
Potter L, Badcock S (2004) Tree crop smallholders, capitalism, and adat: studies in Riau Province, Indonesia. Asia Pac Viewpoint 45(3):341-356

Ribot J, Agrawal A, Larson A (2006) Recentralizing while decentralizing: how national governments reappropriate forest resources. World Dev 34(11):1864-1886

Ribot J, Larson AM (2012) Reducing REDD risks: affirmative policy on an uneven playing field. Int J Commons 6(2):233-254

Rosyadi S, Birner R, Zeller M (2005) Creating political capital to promote devolution in the forestry sector-a case study of the forest communities in Banyumas district, Central Java, Indonesia. For Pol Econ $7(2): 213-226$

Unruh JD (2008) Carbon sequestration in Africa: the land tenure problem. Glob Environ Chang 18(4):700-707

Unruh JD, Cligget L, Hay R (2005) Migrant land reception and 'clearing to claim' in sub-Saharan Africa: a deforestation example from southern Zambia. Nat Res Forum 29:190-198

Van Klinken G (2008) Blood, timber and the state in West Kalimantan, Indonesia. Asia Pac Viewpoint 49(1):35-47

van Noordwijk M, Tata HL, Xu J, Dewi S, Minang P (2012) Segregate or integrate for multifunctionality and sustained change through landscape agroforestry involving rubber in Indonesia and China. In: Nair PKR, Garrity DP (eds) Agroforestry: The future of global landuse. Springer, The Netherlands

Wardell DA, Lund C (2006) Governing access to forests in northern Ghana: micro-politics and the rents of non-enforcement. World Dev 34(11):1887-1906

Widayati A, Suyanto S, van Noordwijk M (2011) Towards reduced emission in a high-stake district REALU project design for Tanjung Jabung Barat (TanJaBar), Jambi, Indonesia, version 2.0. World Agroforestry Centre South East Asia, Bogor, p 143

Wright G (2012) Indigenous people and customary land ownership under domestic REDD frameworks: a case study of Indonesia. Law, Environ Develop J 7(2). http://www.lead-journal.org/content/11117.pdf. Cited on 1 July 2013 